\title{
STRUKTUR KOMUNITAS MOLUSKA (GASTROPODA DAN BIVALVIA) BERDASARKAN KERAPATAN LAMUN DI PERAIRAN DESA LIYA MAWI KABUPATEN WAKATOBI
}

\section{Community Structure of Mollusca (Gastropod and Bivalvia) Based on Seagrass Density in Liya Mawi, Wakatobi}

\author{
Suparman ${ }^{1}$, Muhammad Ramli², Muhammad Fajar Purnama ${ }^{3}$ \\ ${ }^{1}$ Mahasiswa Jurusan Ilmu Kelautan, \\ Fakultas Perikanan dan Ilmu Kelautan, Universitas Halu Oleo. \\ Jl. H.E.A Mokodompit Kampus Hijau Bumi Tridharma Anduonohu Kendari 93232, Telp/Fax: (0401) 3193782 \\ ${ }^{2}$ Surel: muh.ramli@gmail.com \\ ${ }^{3}$ Surel: muhammadfajarpurnama@gmail.com
}

\begin{abstract}
Abstrak
Ekosistem lamun merupakan ekosistem laut dangkal yang mempunyai peranan dalam kehidupan biota laut. Salah satu jenis biota laut yang berada di padang lamun adalah moluska. Dari delapan kelas moluska, dua diantaranya sering ditemukan pada ekosistem lamun yaitu gastropoda dan bivalvia. Penelitian ini bertujuan untuk mengetahui kerapatan lamun dan struktur komunitas Moluska (gastropoda dan bivalvia). Penelitian ini dilakukan pada bulan Mei-Desember 2019 di Perairan Desa Liya Mawi Kabupaten Wakatobi. Pengambilan kerapatan lamun dan struktur komunitas moluska menggunakan transek kuadrat dengan luas area $1 \mathrm{~m}^{2}$ dengan tiga kali pengulangan. Kerapatan jenis lamun di lokasi penelitian tergolong kategori rapat $\left(>100 \mathrm{ind} / \mathrm{m}^{2}\right)$ dan sedang $\left(50-100 \mathrm{ind} / \mathrm{m}^{2}\right)$. Di Perairan ini, terdapat $259 \mathrm{individu}$ moluska yang terdiri dari 15 famili dan 17 jenis, yaitu 10 famili dan 12 jenis dari kelas gastropoda sedangkan kelas bivalvia yaitu 5 famili dari 5 jenis. Kep berkisar antara $\left(6,33-19,67 \mathrm{ind} / \mathrm{m}^{2}\right)$, indeks keanekaragaman berkategori sedang $(1,47-1,69)$, indeks keseragaman berkategori tinggi $(0,74-0,98)$, dan indeks dominansi berkategori rendah $(0,21-0,27)$. Struktur komunitas Moluska (gastropoda dan bivalvia) masih dalam kondisi stabil di lokasi studi.
\end{abstract}

Kata Kunci: Kerapatan lamun, stuktur komunitas, moluska, Desa Liya Mawi

\begin{abstract}
Seagrass ecosystems are found shallow water that play an important role in the growth of marine biota. One type of marine biota that lives in seagrass is mollusca. Of the eight classes of mollusca, two of them are often found in seagrass ecosystems, namely gastropods and bivalves. This study aimed to determine the density of seagrass and community structure of gastropods and bivalves. This research was conducted from May to December 2019 in Liya Mawi Seawaters of Wakatobi. Quadratic transect with 1x1 m was applied to collect data of seagrass and mollusca with three replications. The density of seagrass in the study location was classified into two categories i.e hight density $\left(>100\right.$ ind $\left./ \mathrm{m}^{2}\right)$ and moderate (50-100 ind / $\mathrm{m}^{2}$ ). In the area, there were 259 individuals of mollusca consisting of 15 families and 17 species. Gastropods consisted of 10 families and 12 species while bivalves consisted of 5 families and 5 species. Density of mollusca ranged 6.33-19.67 ind / $\mathrm{m}^{2}$ with moderate categorical of diversity index from 1.47 to 1.69 . Uniformity index was high ranged from 0.74 to 0.98 and dominance index was low which ranged from 0.21 to 0.27 . Community structure of mollusca was still in a stable condition at the study area.
\end{abstract}

Keywords: Seagrass density, community structure, mollusca, Liya Mawi Seawaters

\section{Pendahuluan}

Moluska merupakan kelompok biota laut sebagai komponen penting penyusun ekosistem perairan. Moluska juga merupakan anggota yang terbanyak kedua setelah Arthropoda. Terdapat lebih dari 60.000 spesies hidup dan 15.000 spesies fosil. Umumnya moluska mendiami zona litoral dan termasuk daerah pasang surut. Moluska berperan penting bagi lingkungan perairan yaitu sebagai bioindikator kesehatan lingkungan dan kualitas perairan juga sebagai sumber makanan bagi organisme lain.
Moluska terdiri atas delapan kelas yakni Chaetodermomorpha, Neomeniomorpha, Monoplacophora, Polyplacophora, Gastropoda, Pelecypoda, Scaphopoda dan Cephalopoda. Dari delapan kelas tersebut tiga yang paling penting karena mempunyai arti nilai ekonomi yaitu gastropoda (jenis-jenis siput), Pelecypoda (jenis-jenis kerang), dan Cephalopoda (cumi-cumi, sotong, dan gurita) (Suwignyo et al., 2013).

Ekosistem lamun merupakan ekosistem laut dangkal yang mempunyai 
peranan penting dalam kehidupan berbagai biota laut. Salah satu jenis biota laut ekonomis penting yang berada di padang lamun adalah moluska. Dari delapan kelas moluska dua diantaranya sering ditemukan pada ekosistem lamun yaitu gastropoda dan bivalvia. Gastropoda merupakan hewan moluska yang berjalan dengan bagian kaki perut, berasal dari bahasa Yunani (gaster : perut; podas : kaki) artinya hewan yang memiliki kaki perut sedangkan bivalvia merupakan moluska yang bercangkang setangkup yang pada umumnya simetri bilateral dengan memfungsikan otot aduktor dan reduktornya. Lamun, gastropoda dan bivalvia memiliki keterkaitan salah satunya memiliki karakteristik tipe substrat yang sama yang dijadikan sebagai habitat. Selain itu, asosiasi lamun, gastropoda dan bivalvia mempunyai keterkaitan yang kuat dalam siklus makanan (Sari et al., 2018).

Perairan Desa Liya Mawi terletak di Kecamatan Wangi-Wangi Selatan Kabupaten Wakatobi yang memiliki area padang lamun yang cukup luas. Kerapatan lamun di Desa Liya Mawi memiliki kategori kerapatan yang berbeda-beda dari padat, sedang dan jarang. Komunitas padang lamun di Perairan Desa Liya Mawi memiliki sebaran yang cukup luas, sehingga beragam biota laut potensial berada di padang lamun terutama gastropoda dan bivalvia. Meskipun lamun di Perairan Desa Liya Mawi memiliki potensi yang besar, namun informasi tentang potensi yang dimiliki khususnya kerapatan lamun dan kepatadan biota yang berasosiasi dengan lamun masih sangat minim dan tidak terinformasi dengan baik. Berdasarkan latar belakang diatas, penelitian mengenai Struktur Komunitas Moluska (Gastropod dan Bivalvia) berdasarkan kerapatan Lamun di Perairan Desa Liya Mawi Kecamatan Wangi-Wangi Selatan Kabupaten Wakatobi sangat penting untuk dilakukan.

\section{Bahan dan Metode}

Penelitian dilaksanakan pada bulan Mei-Desember 2019, yang meliputi pengambilan data dan pengolahan data penelitian. Lokasi pengambilan sampel dan data penelitian di Perairan Desa Liya Mawi, Kecamatan Wangi-wangi Selatan, Kabupaten Wakatobi, Provinsi Sulawesi Tenggara. Peta lokasi penelitian dapat dilihat pada Gambar 1.

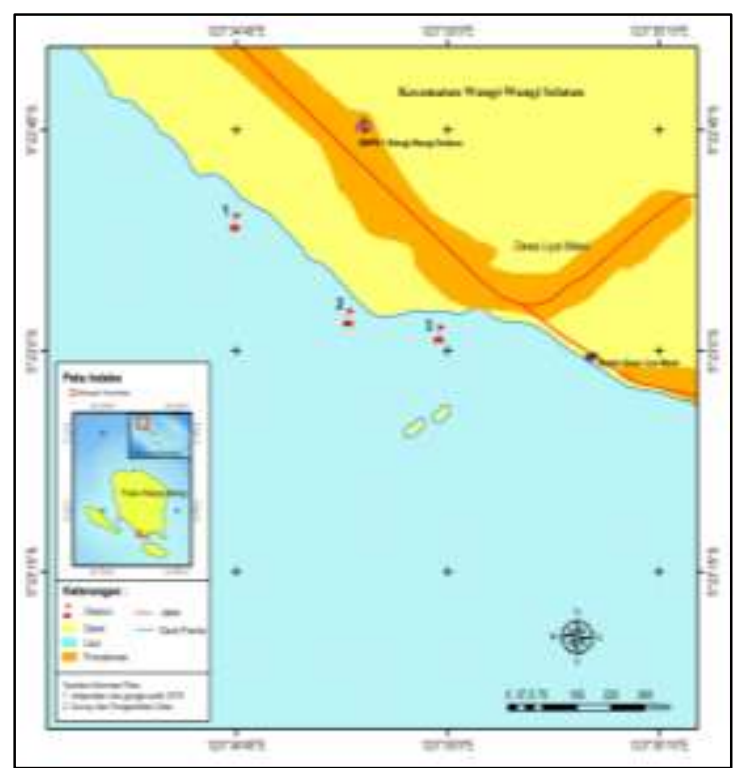

Gambar1.Peta Lokasi Penelitian Perairan Desa Liya Mawi

Survei pendahuluan dilakukan dengan tujuan untuk mengetahui kondisi lokasi penelitian secara menyeluruh dan untuk menentukan stasiun pengambilan sampel. Setelah dilakukan survei pendahuluan, selanjutnya dilakukan penentuan titik stasiun penelitian dengan menggunakan GPS. Titik stasiun pengambilan data yang diamati sebanyak tiga stasiun berdasarkan keberadaan Moluska (gastropoda dan bivalvia) pada ekosistem padang lamun.

Stasiun 1, terletak di bagian Selatan Perairan Desa Liya Mawi, stasiun ini berada pada daerah yang kurang aktivitas masyarakat sehingga memiliki kerapatan lamun yang padat, berada pada titik koordinat $123^{\circ} 34^{\prime} 45^{\prime \prime}$ BT $-5^{0} 22^{\prime} 45^{\prime}$ LS. Stasiun 2, terletak di bagian Selatan Perairan Desa Liya Mawi, stasiun ini berada pada wilayah trasportasi dan tempat berlabuhnya sampan dan kapal-kapal nelayan sehingga memiliki kerapatan lamun yang sedang, berada pada titik koordinat $123^{\circ}$ 35' 0" BT - 50 23' 57' LS. Stasiun 3 : Terletak di bagian Selatan Perairan Desa Liya Mawi, stasiun ini berada pada daerah pemukiman yang dipengaruhi berbagai aktivitas masyarakat sehingga memiliki kerapatan lamun yang sedang, berada pada titik koordinat $123^{\circ} 35^{\prime} 58^{\prime \prime}$ BT $-5^{0} 22$ ' 59" LS.

Pengambilan sampel gastropoda dan bivalvia dilakukan dengan cara menarik rol meter tegak lurus pantai, dengan jarak $100 \mathrm{~m}$. Metode yang digunakan untuk pengambilan sampel di lapangan yaitu menggunakan metode transek kuadrat. Masing-masing 
transek kuadrat $(1 \times 1 \mathrm{~m})$ diletakkan pada transek garis dengan jarak $30 \mathrm{~m}$ dengan cara zig-zag atau (selang seling). Pengambilan data di setiap stasiunya $1 \mathrm{~m}^{2}$ dengan tiga kali pengulangan (Setyobudiandi et al., 2010).

Sampel gastropoda dan bivalvi yang terdapat di dalam transek dihitung jumlah perjenisnya kemudian didokumentasikan dengan menggunakan kamera. Gastropoda dan bivalvi yang tidak dapat diidentifikasi selanjutnya dimasukan ke dalam plastik sampel dan diidentifikasi sesuai dengan panduan (Setyobudiandi et al., 2010).

Pengabilan data lamun dilakukan secara visual di dalam plot yang sama dengan pengambilan contoh Gastropoda pada setiap plot dalam transek (Setyobudiandi et al., 2010). Contoh lamun yang ada di dalam setiap plot diambil dan dimasukkan ke dalam kantong plastik yang telah diberi tanda atau label untuk kemudian diidentifikasi jenisnya. Identifikasi jenis- jenis lamun dengan panduan atau kunci identifikasi oleh Hermawan et al., 2017.

Pengukuran parameter oseanografi yang dilakukan bertujuan untuk menggambarkan kondisi perairan pada lokasi pengamatan dan juga dapat berperan dalam menentukan seberapa besar pengaruh kondisi parameter lingkungan yang menjadi pengamatan dalam penelitian ini meliputi suhu, kecerahan, salinitas, derajat keasaman $(\mathrm{pH})$, Oksigen terlarut (DO), kedalaman, dan Substrat.

\section{Analisi Data}

Kerapatan jenis dilakukan untuk melihat perbandingan antara jumlah total individu (Ni) dengan unit area yang diukur (A). Kerapatan jenis lamun dapat dihitung berdasarkan persamaan (Putra, 2014):

$\mathrm{Ki}=\frac{n_{i}}{A}$

Keterangan :

$\mathrm{Ki}=$ Kerapatan jenis ke i (tegakan $/ \mathrm{m}^{2}$ )

$\mathrm{ni}=$ Jumlah total dari jenis ke-i (ind)

$A=$ Luas pengambilan sampel $\left(\mathrm{m}^{2}\right)$

Tabel 1. Kriteria kerapatan lamun menurut (Putra, 2014) sebagai berikut:

\begin{tabular}{cc}
\hline Kerapatan & Kriteria \\
\hline$>100 \mathrm{ind} / \mathrm{m}^{2}$ & rapat/lebat \\
$50-100 \mathrm{ind} / \mathrm{m}^{2}$ & sedang $/$ kurang padat \\
$<50 \mathrm{ind} / \mathrm{m}^{2}$ & sangat jarang \\
\hline
\end{tabular}

Kepadatan adalah jumlah individu persatuan luas. Kepadatan masing-masing spesies dari semua transek pada setiap titik stasiun dihitung menggunakan rumus sebagai berikut (Fachrul, 2007) .

$\mathrm{D}=\frac{n_{i}}{A}$

Keterangan :

$\mathrm{Di}=$ Kepadatan individu jenis ke-i $\left(\mathrm{ind} / \mathrm{m}^{2}\right)$

ni $=$ Jumlah individu jenis ke-i yang

diperoleh

$\mathrm{A}=$ Luas total area pengambilan contoh

Indeks Keanekaragaman spesies dmenggunakan rumus Shannon-Weiner menurut Setyobudiandi et al., (2010),

$H^{\prime}=-\sum_{i=1}^{n} P i \cdot \ln P i$

Keterangan :

$\mathrm{H}^{\prime}=$ Indeks keanekaragaman

$\mathrm{Pi}=n \mathrm{ni} / \mathrm{N}$

ni $=$ Jumlah individu jenis ke-I

$\mathrm{N}=$ Jumlah total individu semua jenis ke-i

Kriteria hasil keanekaragaman $\left(\mathrm{H}^{\prime}\right)$

adalah sebagai berikut :

$\mathrm{H}^{\prime} \leq 1$ = keanekaragaman rendah

$1<\mathrm{H}^{\prime}<3=$ keanekaragaman sedang

H'> $3.0=$ keanekaragaman tinggi

Keseragaman merupakan komposisi individu tiap spesies yang terdapat dalam. Indeks keseragaman (Odum, 1998) yaitu :

$\mathrm{E}=\frac{H^{\prime}}{H_{\text {maks }}}$

Keterangan :

$\mathrm{E}=$ Indeks keseragaman

$\mathrm{H}^{\prime}=$ indeks keanekaragaman

$\mathrm{H}^{1}$ maks $=$ Indeks keanekaragaman maksimum $=\log 2 \mathrm{~S}=3,3219 \log \mathrm{S}$ (dimana $\mathrm{S}=$ jumlah jenis)

Kriteria indeks keseragaman menurut (Odum, 1998) sebagai berikut:

$\mathrm{E}<0,4=$ rendah

$0,4-0,6=$ sedang

E $>0,6=$ stabil

Indeks Dominansi dihitung dengan menggunakan rumus indeks dominanasi dari Simpson (Odum, 1998).

$C=\sum\left(\frac{n_{i}}{N}\right)^{2}$

Keterangan :

$\mathrm{C}=$ Indeks dominansi simpson

$\mathrm{ni}=$ Jumlah individu tiap spesies

$\mathrm{N}=$ Jumlah individu seluruh spesies

Kriteria indeks dominansi menurut

(Septiani, 2017) sebagai berikut:

$00,0<\mathrm{C} \leq 0,30=$ Dominansi rendah

$0,30<\mathrm{C} \leq 0,60=$ Dominansi sedang

$0,60<\mathrm{C} \leq 1,00=$ Dominansi tinggi 


\section{Hasil dan Pembahasan}

Lamun yang ditemukan pada lokasi penelitian terdapat dua jenis yaitu, Thalassi hemprichii, dan Cymodecea serrulata. Hasil analisis kerapatan jenis lamun (Ki) yang terdapat pada ketiga stasiun penelitian menunjukan kategori tinggi dan kategori sedang. Pada stasiun I memiliki nilai kerapatan dengan kategori tinggi $\left(141.00 \mathrm{ind} / \mathrm{m}^{2}\right)$, pada stasiun II memiliki nilai kerapatan 89.67 ind $/ \mathrm{m}^{2}$ dan pada stasiun III memiliki nilai kerapatan $77.33 \mathrm{ind} / \mathrm{m}^{2}$ dengan kategori sedang.

Hasil identifikasi moluska menunjukan bahwa di Perairan Desa Liya Mawi terdapat 259 individu yang terdiri dari 15 famili dan 17 jenis, yaitu 10 famili dan 12 jenis dari kelas gastropoda sedangkan kelas bivalvia yaitu 5 famili dari 5 jenis. Kelas gastropoda didominasi oleh Trochus viridis, Trivia oryza Lamarck, Nassarius coronatus bruguiera, dan Vexillum gruneri reeve. Sedangkan dari kelas bivalvia didominasi oleh Mactra grandis, Modiolus metcalfei, Trachycardium flavula. Merupakan jenis yang banyak ditemukan pada stasiun pengamatan. Kerapatan lamun di Perairan Deasa Liya Mawi dari ketiga stasiun penelitia masih dalam kondisi yang baik dengan suhu berkisar antara $29-32^{\circ} \mathrm{C}$ yang masih merupakan kisaran suhu yang baik untuk menunjang kehidupan lamun. Hal ini sesuai dengan pernyataan Christon et al., (2012) menyatakan pertumbuhan lamun di daerah tropis yaitu $23-32^{\circ} \mathrm{C}$ Selanjutnya menurut KepmenLH NO.51 (2004), bahwa kisaran optimal bagi kehidupan lamun diantaranya pada kisaran $28-30^{\circ} \mathrm{C}$.

Salinitas berkisar antara $31-32 \%$, salinitas tersebut dapat diterima untuk kehidupan lamun. Menurut (Ekaningrum et al., 2012).Kisaran salinitas yang dapat ditolerir tumbuhan lamun adalah 10-40\%o dan nilai optimumnya adalah $35 \%$. Nilai rata-rata $\mathrm{pH}$ perairan adalah 7 , nilain ini masih optimal untuk kehidupan lamun. secara keselurahan kondisi Derajat Keasaman masih sesuai untuk kehidupan lamun. Mengacu pada KEPMEN LH N0. 51 Tahun 2004 kisaran derajat keasaman optimul untuk kehidupan lamun berkisar $7-8,5$. Oksigen terlarut (DO) berkisar antara 4,9-5,7 ppm. Nilai kandungan oksigen terlarut tersebut termasuk dalam standar baku mutu air laut yaitu di atas 5 mg/L (KMNLH N0 51, 2004). Salmin (2005) mengatakan bahwa suatu perairan dikategorikan berkondisi baik jika kandungan oksigen terlarut lebih dari 5 ppm. Kecepatan arus berkisar antara 0,07-0,08 $\mathrm{m} /$ det. Nilai tersebut menunjukan bahwa kecepatan arus di pearairan ini masih dalam kisaran yang baik untuk kehidupan lamun. Hal ini sesuai dengan Hasanah (2014) bahwa kecepatan arus 0,010,10 merupakan kecepatan arus yang baik untuk pertumbuhan lamun.

Berdasarkan hasil penelitian yang dilakukan di Perairan Deas Liya Mawi mengenai struktur komunitas moluska (gastropoda dan bivalvia). Terdapat $259 \mathrm{ind} / \mathrm{m}^{2}$ moluska yang terdiri dari 15 famili dan 17 jenis, yaitu 12 jenis dari 10 famili kelas gastropoda dan 5 famili dari 5 jenis kelas bivalvia. Indeks kepadatan gastropoda yang tertinggi berada pada stasiun II sedangkan nilai kepadatan bivalvia yang tertinggi yaitu pada stasiun I, namun semua pengamatan masuk dalam kategori tinggi (18,33-19,67 ind $\left./ \mathrm{m}^{2}\right)$. Kepadatan gastropoda pada stasiun II lebih tinggi dibandingkan stasiun lainnya dikarenakan di daerah ini, memiliki tingkat kerapatan lamun berkriteria sedang $(89,66$ $\mathrm{ind} / \mathrm{m}^{2}$ ). Tingkat kerapatan lamun yang tinggi dapat menyebabkan aktivitas gastropoda terhambat. menurut (Syari, 2005) bahwa tingkat kerapatan lamun yang tinggi dapat menyebabkan terhambatnya aktivitas dari makrozoobentos terutama pada filum moluska dimana sistem perakaran lamun yang menjadi semakin rapat dapat menyebabkan tidak adanya ruang yang cukup ideal bagi pergerakan moluska.

Tabel 2. Hasil kerapatan lamun yang ada di Perairan Desa Liya Mawi

\begin{tabular}{|c|c|c|c|c|c|}
\hline No & Jenis lamun & Stasiun & $\begin{array}{l}\text { Jumlah } \\
\text { tegakan }\end{array}$ & $\begin{array}{l}\text { Kerapatan } \\
\text { (ki) }\end{array}$ & $\begin{array}{c}\text { Total } \\
\text { kerapatan }\end{array}$ \\
\hline \multirow{2}{*}{1.} & C. serrulata & & 219 & 73.00 & \multirow{2}{*}{141.00} \\
\hline & T. hempricih & 1 & 204 & 68.00 & \\
\hline \multirow{2}{*}{2.} & C. serrulata & \multirow{2}{*}{ II } & 82 & 27.33 & \multirow{2}{*}{89.66} \\
\hline & T. hempricih & & 187 & 62.33 & \\
\hline & C. serrulata & \multirow{2}{*}{ III } & 80 & 26.67 & \multirow{2}{*}{77.34} \\
\hline & T. hempricih & & 152 & 50.67 & \\
\hline
\end{tabular}


Tabel 3. Struktur komunitas bivalvia di Perairan Desa Liya Mawi secara keseluruhan

\begin{tabular}{lrrrc}
\hline \multicolumn{1}{c}{ Struktur Komunitas } & \multicolumn{3}{c}{ Stasiun pengamatan } & \multirow{2}{*}{ Kategori } \\
\cline { 2 - 4 } Gastropoda & I & II & III & \\
\hline Kepadatan (D) & 18.33 & 19.67 & 18.67 & - \\
Keanekaragaman (H') & 1.69 & 1.63 & 1.65 & Sedang \\
Keseragaman (E) & 0.87 & 0.74 & 0.85 & Stabil \\
Dominansi (D) & 0.23 & 0.27 & 0.26 & Rendah \\
\hline \multicolumn{1}{c}{ Struktus komunitas } & & & & \\
$\quad$ bivalvia & 16.00 & 7.33 & 6.33 & - \\
\hline Kepadatan (D) & 1.47 & 1.58 & 1.52 & Sedang \\
Keanekaragaman (H') & 0.91 & 0.98 & 0.94 & Stabil \\
Keseragaman (E) & 0.25 & 0.21 & 0.24 & Rendah \\
Dominansi (D) & & & & \\
\hline
\end{tabular}

Stasiun II memiliki substrat pasir berlumpur yang mampu mendukung kehidupan gastropoda. Substrat berpasir memiliki kandungan oksigen relative besar disbanding substrat yang halus, karena pada substrat berpasir tardapaat pori - pori udara yang berfungsi sebagai tempat terjadinya percampuran nutrien yang lebih intensif dengan air diatasnya, sehingga berpangaruh terhadap kepadatan gastropoda (Nugroho et al., 2012). Menurut Yulinda, (2018) menyatakan bahwa gastropoda relatif melimpah pada substrat yang memiliki kandungan substrat pasir berlumpur atau lumpur berpasir karena beberapa jenis gastropoda memakan baangkai-bangkai hewan (scavenger feeder) dan beberapa partikel pasir permukaan untuk menyerap partikel organik yang terdapat didalamnya. Seadangkan kepadatan bivalvia pada stasiun I lebih tinggi $\left(16,00 \mathrm{ind} / \mathrm{m}^{2}\right)$ dibanding dengan stasiun lainya dikarenakan pada stasiun ini memiliki tingkat kerapatan lamun berkriteria tinggi $\left(141,00\right.$ tegakan $\left./ \mathrm{m}^{2}\right)$ selain itu stasiun I memiliki substrat pasir berlumpur. Hal ini sesuai dengan pernyataan Hermala (2015) bahwa Lamun dan bivalvia memiliki keterkaitan salah satunya memiliki karakterisitik tipe substrat yang sama yang dijadikan sebagai habitat. Selain itu, asosiasi lamun dan bivalvia mempunyai keterkaitan yang kuat dalam siklus makanan. Serasah pada lamun akan mengendap didasar perairan yang kemudian diuraikan oleh mikroganisme yang menjadi makanan bivalvia sedangkan hasil penguraian akan menjadi sumber makanan bagi larva, ikan - ikan kecil dan selanjutnya menjadi makanan bagi biota lain.
Indeks keanekaragaman gastropoda tertinggi yaitu pada stasiun I sedangkan indeks keanekaragaman bivalvia tertinggi pada stasiun II, namun semua stasiun pangmatan masuk dalam kategori sedang, artinya proposri jumlah individu gastropoda dan bivalvia relarif merata disetiap stasiun, yang berarti ekosistem yang ada di Perairan Desa Liya Mawi dalam keadaan seimbang serta kondisi komunitas yang tidak mudah berubah karena pengaruh lingkungan yang relative kecil. Menurut Latuconsina et al., (2013) menyatakan bahwa suatu komunitas dikatakan memiliki keanekaragaman tinggi jika proporsi antara jenis secara keseluruhan sama banyak sehingga jika ada beberapa jenis memiliki dominansi besar maka keanekaragaman dan keseragamannya rendah.

Indeks keseragaman gastropoda pada setiap stasiun yaitu, stasiun I dengan nilai 0.87 ind $/ \mathrm{m}^{2}$, stasiun II $0.74 \mathrm{ind} / \mathrm{m}^{2}$, dan stasiun III $0.85 \mathrm{ind} / \mathrm{m}^{2}$, seadngkan nilai keseragamn bivalvia yaitu, stasiun I $0.90 \mathrm{ind} / \mathrm{m}^{2}$, stasiun II $0.95 \mathrm{ind} / \mathrm{m}^{2}$, dan stasiun III $0.92 \mathrm{ind} / \mathrm{m}^{2}$. Nilai keseragaman gastropoda dan bivalvia pada setiap stasiun menunjukan bahwa kondisi ekosistem gastropoda dan bivalvia masih dalam kondisi stabil dan memiliki keseragaman tinggi. Menurut Irawan (2008) menyatakan bahwa kestabilan suatu komunitas dapat digambarkan dengan tinggi rendahnya nilai indeks keseragaman jenis (E) yang didapat. Kondisi komunitas dikatakan stabil atau tinggi bila memiliki nilai keseragaman jenis mendekati 1 . Semakin kecil nilai keseragaman (E) mengindikasikan bahwa penyebarann jenis tidak merata sedangkan semakin besar nilai (E) maka penyebaran jenis relative merata. 
Indeks dominansi gastropoda stasiun I $0.23 \mathrm{ind} / \mathrm{m}^{2}$, stasiun II, $0.27 \mathrm{ind} / \mathrm{m}^{2}$, dan stasiun III $0.26 \mathrm{ind} / \mathrm{m}^{2}$, sedangkan nilai dominansi bivalvia pada setiap stasiun yaitu, pada stasiun I $0.25 \mathrm{ind} / \mathrm{m}^{2}$, stasiun II 0.21 ind $/ \mathrm{m}^{2}$, stasiun III $0.24 \mathrm{ind} / \mathrm{m}^{2}$. Hal ini menunjukkan bahwa tidak ada individu yang dominan di daerah penelitian artinya bahwa belum terjadi persaingan yang berarti terhadap ruang, makanan, atau tempat hidup bagi organisme Mollusca tersebut. Hal ini diperkuat oleh pernyataan Syamsurial (2011) yang menyatakan bahwa nilai indeks dominasi yang tinggi menyatakan konsentrasi dominan yang tinggi (adanya individu yang dominan), sebaliknya jika indeks dominasi rendah menyatakan konsentrasi dominan yang rendah (tidak ada yang dominan).

\section{Kesimpulan}

Berdasarkan hasil penelitian yang telah dilakukan di Perairan Deasa Liaya Mawi dapat disimpulkan yaitu sebagai berikut:

1. Kerapatan jenis lamun di Perairan Deasa Liaya Mawi masih tergolong kategori rapat $\left(141,00\right.$ tegakan $\left./ \mathrm{m}^{2}\right)$ dan sedang $\left(89,66-77,34\right.$ tegakan $\left./ \mathrm{m}^{2}\right)$ sedangkan jenis lamun yang ditemukan yaitu, $T$. hemprichii, dan C. serrulata.

2. Struktur komunitas moluska (gastropoda dan bivalvia) berdasarkan kerapatan lamun di Perairan Desa Liya Mawi yaitu, indeks keanekaragaman berkategori sedang $(1,47$ 1,69), indeks keseragaman berkategori tinggi $(0,74-0,98)$, dan indeks dominansi berkategori rendah $(0,21-0,27)$ sedangkan kepadatan gastropoda dan bivalvia berbeda. Nilai kepadatan gastropoda tinggi $(19,67)$ pada ekosistem lamun berkriteria sedang dan nilai kepadatan bivalvia tinggi $(16,00)$ pada ekosistem lamun berkriteria tinggi.

\section{Daftar Pustaka}

Christon, Otong S.D., dan Noir P.P. 2012. Pengaruh Tinggi Pasang Surut Terhadap Pertumbuhan Dan Biomassa Daun Lamun Enhalus acoroides di Pulau Pari Kepulauan Serubu Jakarta. Jurnal Perikanan dan Kelautan. Vol.3(3):287-294.

Ekaningrum N., Ruswahyuni dan Suryanti. 2012. Kelimpahan Hewan Makrobentos Yang Berasosiasi Pada Habitat Lamun Deangan Jarak Berbeda di Perairan
Pulau Pramuka Kepulauan Seribu. Journal Of Management Of Akuatic Resources. 1(1) : 1-6.

Fachrul MF. 2007. Metode Sampling Bioekologi. Jakarta: Bumi Aksara. hlm 146-154.

Hasanah. 2014. Efek umur Semaian Lamun Enhalus acoroides terhadap Pertumbuhan dan Sintasannya saat ditanam Di Pulau Barranglompo. Skripsi. Makasar.

Hermala. 2015. Hubungan Kerapatan Lamun dengan Kelimpahan Bivalvia di Pesisir Pantai Dolpin Desa Teluk Bakau Kabupaten Bintan. [skripsi] Universitas Maritim Raja Ali Haji. Tanjungpinang.

Hermawan, U.E., Sjafrie, N.D.M., Supriyadi, I.H., Suyarso., Iswari, M.Y., Anggraini, K., dan Rahmat. 2017. Status Padang Lamun Indonesia. Pusat Penelitian Oseanografi. Lembaga Ilmu Pengetahuan Indonesia.

Irawan, I. 2008. Struktur Kominitas Moluska (Gastropoda Dan Bivalvia) Serta Distribusinya Di Pulau Burung Dan Pulau Tikus, Gugusan Pulau Pari, Kepulauan Seribu. Institusi Pertanian Bogor. Skripsi.

KMNLH (Kantor Menteri Negara Lingkungan Hidup). 2004. Keputusan Menteri Negara Lingkungan Hidup No.51 Tahun 2004 Tentang Baku Mutu Air Laut. Kementerian Negara dan Lingkungan Hidup. Jakarta.

Latuconsina, H., Sangatji, M., Dawar, La. 2013. Asosiasi Gastropoda Pada Habitat Lamun Berbeda Di Perairan Pulau Osi Teluk Kotania Kabupaten Seram Barat. Torani (jurnal IKP). Vol 23 (2): 67-78.

Nugroho KD, Suryono CA, Irwani. 2012. Struktur komunitas gastropoda di Perairan Pesisir Kecamatan Gemuk Kota Semarang. Journal of Marine Research. 1(1):7.

Odum, E.P. 1998. Dasar-dasar Ekologi. Edisi Keempat. Alih Bahasa Oleh T. Jahjono. FMIPA. IPB. Gadjah Mada University Press. Yogyakarta. Hlm. 370-375.

Putra, I.P., 2014. Kajian Kerapatan Lamun terhadap Kepadatan Siput Gonggong (Strombus canarium) di Perairan Pulau Penyengat Kepulaun Riau. Kelautan dan Perikanan. 3(12): 25-67. 
Salmin. 2005. Oksigen Terlarut dan Kebutuhan Oksigen Biologi (BOD) sebagai Salah Satu Indikator untuk Menentukan Kualitas Perairan. Oseana 30 (3): 21-26

Sari, P,D, Lestari, F, Kurniawan, D. 2018. Hubungan Kerapatan Lamun Bivalvia Di perairan Desa Pangudang Kabupaten Bintan. Fakultas Ilmu Kelautan dan Perikanan,Universitas Maritim. Raja Ali Haji. Hal 2-18.

Septiani, N. I. 2017. Keanekaragaman Moluska (Bivalvia dan Gastropoda) di Pantai Pasir Putih Kabupaten Lampung Selatan. Skripsi Fakultas Tarbiyah dan Keguruan Universitas Islam Negeri Raden Intan Lampung: hal.48.

Setyobudiandi I, Yulianda F, Juariah U, Abukenan SL. Amiluddin NM dan Bahtiar. 2010. Gastropoda dan Bivalvia: Biota Laut - Mollusca. Indonesia. STP Hatta - Sjahrir. Banda Naira.

Suwignyo, S, Widigdo, B, Wardianto, Y. 2013. Buku Avertebrata Air. Penerbit Swadaya. Hal 208.

Syamsurial. 2011. Studi Beberapa Indeks Komunitas Makrozoobentos di Hutan Mangrove Kelurahan Coppo Kabupaten Baru. Skripsi Program Studi Perikanan Fakultas Ilmu Kelautan dan Perikanan Universitas Hasanudin. Makasar.

Syari, I.A. 2005. Asosiasi Gastropoda Di Ekosistem Padang Lamun Perairan Pulau Lepar Provinsi Kepulauan Bangka Belitung. Skripsi. Institut Pertanian Bogor. Bogor.

Yulinda, E. 2018. Korelasi Antara Kerapatan Lamun Dengan Kepadatan Gastropoda Di Perairan Pulau Poncan Gadang Kota Sibolga Provinsi Sumatera Utara. Pekanbaru. Skripsi. 